\title{
Apolipoprotein A5 gene variants and the risk of coronary heart disease: A case-control study and meta-analysis
}

\author{
JIANQING ZHOU ${ }^{1 *}$, LIMIN XU ${ }^{2 *}$, RONG STEPHANIE HUANG ${ }^{3}$, YI HUANG ${ }^{2}$, YANPING LE ${ }^{2}$, \\ DANJIE JIANG $^{2}$, XI YANG ${ }^{1}$, WEIFENG XU ${ }^{1}$, XIAOYAN HUANG ${ }^{1}$, CHANGZHENG DONG $^{2}$, \\ MENG YE $^{2}$, JIANGFANG LIAN ${ }^{1}$ and SHIWEI DUAN ${ }^{2}$ \\ ${ }^{1}$ Ningbo Medical Center, Lihuili Hospital, Ningbo University, Ningbo, Zhejiang 315041; \\ ${ }^{2}$ Zhejiang Provincial Key Laboratory of Pathophysiology, Ningbo University School of Medicine, Ningbo, \\ Zhejiang 315211, P.R. China; ${ }^{3}$ Department of Medicine, University of Chicago, Chicago, IL 60637, USA
}

Received January 15, 2013; Accepted August 12, 2013

DOI: $10.3892 / \mathrm{mmr} .2013 .1642$

\begin{abstract}
Previous studies have shown that apolipoprotein A5 (APOA5) gene variants are genetic determinants of the concentration of triglycerides, which are a known risk factor for coronary heart disease (CHD). Using the standardized coronary angiography method, 290 CHD patients and 198 non-CHD controls were recruited from Ningbo Lihuili Hospital. In addition, 331 unrelated healthy volunteers were recruited as healthy controls from Ningbo Ximen Community residents. Three variants of the APOA5 gene, $\mathrm{S} 19 \mathrm{~W},-1131 \mathrm{~T}>\mathrm{C}$ and $553 \mathrm{G}>\mathrm{T}$, were analyzed for their association with CHD. Under a dominant inheritance model, $-1131 \mathrm{CT}>\mathrm{C}$ was shown to be a CHD risk factor $(\mathrm{P}=0.030$; OR, $1.422 ; 95 \% \mathrm{CI}$, 1.036-1.952). The single nucleotide polymorphism, 553G $>\mathrm{T}$, was found to correlate with the severity of CHD in males $(\mathrm{P}=0.032)$. Meta-analysis showed that $-1131 \mathrm{~T}>\mathrm{C}$ was significantly associated with CHD $(\mathrm{P}<0.0001)$. By contrast, negative correlations with CHD were observed for $\mathrm{S} 19 \mathrm{~W}$ and $553 \mathrm{G}>\mathrm{T}$. In the present case-control study, $A P O A 5$ gene variants were not found to correlate with the risk of CHD in the populations studied; however, $-1131 \mathrm{CT}>\mathrm{C}$ was shown to be a CHD risk
\end{abstract}

Correspondence to: Professor Shiwei Duan, Zhejiang Provincial Key Laboratory of Pathophysiology, Ningbo University School of Medicine, 818 Fenghua Road, Ningbo, Zhejiang 315211, P.R. China E-mail: duanshiwei@nbu.edu.cn

Professor Jiangfang Lian, Ningbo Medical Center, Lihuili Hospital, Ningbo University, 57 Xingning Road, Ningbo, Zhejiang 315041, P.R. China

E-mail: hjmpin@163.com

"Contributed equally

Abbreviations: SNP, single nucleotide polymorphism; CHD, coronary heart disease; HWE, Hardy-Weinberg equilibrium; GWAS, genome-wide association studies; APOA5, apolipoprotein A5; TG, triglyceride; OR, odds ratio; CI, confidence interval

Key words: coronary heart disease, APOA5, SNP, -1131T>C, S19W, $553 \mathrm{G}>\mathrm{T}$ factor under a dominant inheritance model. Meta-analysis showed a significant contribution of $-1131 \mathrm{~T}>\mathrm{C}$ to the risk of CHD, implying an ethnic difference in APOA5 gene variants.

\section{Introduction}

Coronary heart disease (CHD) is a severe condition in which plaque builds up inside the coronary arteries. Over time, plaque hardens and narrows the coronary arteries, eventually leading to myocardic infarction and mortality. Triglycerides (TGs) are the major components of plaque and aberrant levels of TGs significantly correlate with the risk of CHD (1). Increased TGs contribute to the development of hypertriglyceridemia and metabolic syndrome $(2,3)$, which are associated with cardiovascular events (2). Although a small number of candidate genes have been identified for the risk of CHD, it is estimated that $95 \%$ of genetic factors remain unidentified in elucidating the pathogenesis of this complex disease (4).

Apolipoprotein A-V (ApoA-V) is a key regulator of TG levels $(5,6)$ and apolipoprotein A5 (APOA5) gene variants, including -1131T>C (rs662799) and S19W (rs3135506). These genetic variants have been significantly associated with TG levels (7-9) and the risk of CHD (10). TG levels have been shown to be significantly higher in -1131C controls compared with $-1131 \mathrm{~T}$ controls $(7,8)$. In addition, the $-1131 \mathrm{C}$ allele frequency of the APOA5 gene in the early-onset CHD group $(43.2 \%)$ has been observed to be significantly higher than that in a control group (33.0\%) (10). In the S19W variant, the minor allele $19 \mathrm{~W}$ was found to be rare in the Chinese (0-4.7\%) (11) in contrast to that of $15 \%$ of the Latin American populations (12). Despite the low minor allele frequency, a positive correlation was found between the 19W allele and CHD in the Chinese population $(8,12)$. In addition, another variant, $553 \mathrm{G}>\mathrm{T}$ (rs2075291), was shown as a risk factor for CHD in the Han Chinese population $(13,14)$. However, conflicting results of $A P O A 5$ variants were observed in a number of other studies $(6,15,16)$. Studies showed that S19W and $-1131 \mathrm{~T}>\mathrm{C}$ were not associated with the risk of CHD in Italian (6) and Brazilian populations (15). The $19 \mathrm{~W}$ allele was not identified as a risk factor for stroke in Hungarian populations (16). Since previous epidemiological studies indicate that there is an 
ethnic difference in the APOA5 gene variants, a meta-analysis of the available data was necessary to investigate the role of the APOA5 gene in the risk of CHD.

The aim of the current study was to assess whether the APOA 5 gene variants, $-1131 \mathrm{~T}>\mathrm{C}, \mathrm{S} 19 \mathrm{~W}$ and $553 \mathrm{G}>\mathrm{T}$, are associated with $\mathrm{CHD}$ in the populations studied and to evaluate the contribution of APOA5 gene variants to $\mathrm{CHD}$ in various ethnic populations by meta-analysis.

\section{Materials and methods}

Sample collection. A total of 819 unrelated individuals were recruited for the case-control study. These included 290 CHD cases, 198 non-CHD controls and 331 healthy controls. CHD cases were patients with $>50 \%$ coronary artery occlusion of one or more major coronary arteries (17) or a history of prior angioplasty or coronary artery bypass surgery. Non-CHD participants were selected from inpatients who had $<50 \%$ occlusion in the major coronary artery (18) and did not have any atherosclerotic vascular disease. In addition, 331 apparently healthy individuals from the Ximen Community residents in Ningbo were recruited as healthy controls. CHD cases and non-CHD controls were collected from the Lihuili Hospital (Ningbo, China). CHD cases and non-CHD controls had been examined by standardized coronary angiography according to Seldinger's method (19) and assessed by at least two independent cardiologists. Subjects were excluded from this study if the individual had congenital heart disease, cardiomyopathy, liver or renal disease or cancer. Blood samples were stored at $-80^{\circ} \mathrm{C}$ until analysis was performed and were treated by the same investigators. The study was approved by the Ethical Committee of Lihuili Hospital in Ningbo (Zhejiang, China) and informed written consent was obtained from all subjects.

Single nucleotide polymorphism (SNP) genotyping. Human genomic DNA was prepared from peripheral blood samples using the Lab-Aid 820 nucleic acid extraction automatic analyzer (Zeesan Biotech, Xiamen, China) and was quantified using the Quant-iT ${ }^{\mathrm{TM}}$ PicoGreen ${ }^{\circledR}$ dsDNA assay kit (Molecular Probes, Inc., Eugene, OR, USA). Amplification was performed on the Geneamp ${ }^{\circledR}$ PCR System 9700 Dual 384-Well Sample Block Module (Applied Biosystems, Foster City, CA, USA) for polymerase chain reaction (PCR). Primers for the single base extension reaction are shown in Table I. The distinct mass of the extended primer indicates different SNP alleles. PCR conditions included an initial denaturation stage at $94^{\circ} \mathrm{C}$ for $15 \mathrm{sec}$, followed by 45 cycles at $94^{\circ} \mathrm{C}$ for $20 \mathrm{sec}, 56^{\circ} \mathrm{C}$ for $30 \mathrm{sec}$ and primer extension at $72^{\circ} \mathrm{C}$ for $1 \mathrm{~min}$ and a final extension for $3 \mathrm{~min}$ at $72^{\circ} \mathrm{C}$. Primer extension for genotyping was performed on the Sequenom MassARRAY iPLEX ${ }^{\circledR}$ platform (Sequenom, San Diego, CA, USA) according to the manufacturer's instructions (20). The primer extension reaction included an initial denaturation stage at $94^{\circ} \mathrm{C}$ for $30 \mathrm{sec}$, followed by 40 cycles of amplification, including $94^{\circ} \mathrm{C}$ for $5 \mathrm{sec}, 52^{\circ} \mathrm{C}$ for $5 \mathrm{sec}$ and $80^{\circ} \mathrm{C}$ for $5 \mathrm{sec}$, and 5 cycles of amplification, including $52^{\circ} \mathrm{C}$ for $5 \mathrm{sec}$ and $80^{\circ} \mathrm{C}$ for $5 \mathrm{sec}$, and a final extension for $3 \mathrm{~min}$ at $72^{\circ} \mathrm{C}$. Following purification, the products were subjected to MALDI-TOF mass spectrometry for SNP genotyping using a SpectroCHIP array (Sequenom, San Diego, CA, USA). To verify the repeatability and stability of the experiment, $5 \%$ of random samples and 18 control samples, including 9 negative and 9 positive controls, were used for quality control.

Retrieval of published studies. A search of the studies on APOA5 gene variants and CHD was conducted in electronic databases, including the Chinese National Knowledge infrastructure, PubMed, Embase, SpringerLink and ScienceDirect, between 2001 and 2012. Specific combinations of keywords were used for the following Medical Subject Heading terms, including 'coronary heart disease', 'coronary artery disease' or 'myocardial infarction' combined with 'APOA5', 'apolipoprotein A5', 'C56G', 'S19W', '-1131T>C' or '553G>T' and 'single nucleotide polymorphism', 'SNP' or 'genetic association'. All studies were considered eligible if they aimed to investigate the correlation between APOA5 and the risk of CHD. For meta-analysis, studies with one of the following conditions were excluded: i) Studies lacking controls, ii) a lack of detailed main allele or genotype information and iii) duplicate publications.

Statistical analysis. Departure of Hardy-Weinberg equilibrium (HWE) was analyzed by Arlequin program version 3.5 (21). The allele frequencies and genotype distribution between CHD patients and each of the 2 control groups were compared by CLUMP16 software (Department of Psychological Medicine, Institute of Psychiatry, Denmark Hill, London, UK) with 10,000 Monte Carlo simulations (22). Linkage disequilibrium of APOA5 gene variants was measured by an online calculator (http://www.oege.orgsoftware/cubex/). Haplotype frequencies were inferred by Arlequin program version 3.5 based on the expectation-maximization algorithm. The odds ratio (OR) with $95 \%$ confidence interval $(95 \% \mathrm{CI})$ was calculated by an

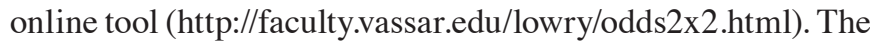
statistical power of the study was calculated by the PS power and sample size calculation software version 3.0.43 (23). The correlation between the variants and the severity of CHD was analyzed by the R statistics software (University of Auckland, Auckland, New Zealand). Severity grade of CHD was defined by the number of major coronary arteries with $>50 \%$ occlusion. Meta-analysis was performed using the Review Manager version 5.1 (The Cochrane Collaboration, The Nordic Cochrane Centre, Copenhagen, Denmark). Heterogeneity of the studies in the meta-analysis was assessed with the $\mathrm{Q}$ and $\mathrm{I}^{2}$ tests. Publication bias was presented using funnel plots by Review Manager 5.1. The type I error rate was set at 0.05. Two-tailed $\mathrm{P}<0.05$ was considered to indicate a statistically significant difference.

\section{Results}

Case-control study in Han Chinese populations. SNP S19W was monomorphic in samples of the current study and thus, discarded from further analysis. SNPs $-1131 \mathrm{~T}>\mathrm{C}$ and $553 \mathrm{G}>\mathrm{T}$ were consistent with HWE ( $\mathrm{P}>0.05)$. As shown in Table II, no significant differences in the 2 SNPs were observed between CHD cases and each of the 2 control groups $(\mathrm{P}>0.05)$. Haplotypes of the 2 SNPs were associated with the risk of CHD (data not shown). Under the dominant inheritance model, $-1131 \mathrm{C}$ was observed to be a CHD risk factor $(\mathrm{P}=0.030$; OR, 1.422; 95\% CI, 1.036-1.952; Table III). Further breakdown 
Table I. Primer sequences for single base extension reaction.

\begin{tabular}{|c|c|c|c|}
\hline SNP & Name & Primer & Sequence $\left(5^{\prime}-3^{\prime}\right)$ \\
\hline rs662799 & $-1131 \mathrm{~T}>\mathrm{C}$ & $\begin{array}{l}\text { 1st-P } \\
\text { 2nd-P } \\
\text { UEP_SEQ }\end{array}$ & $\begin{array}{l}\text { ACGTTGGATGGCCCTGCGAGTGGAGTTCA } \\
\text { ACGTTGGATGACTCTGAGCCCCAGGAACT } \\
\text { GGGTGAACTGGAGCGAAAGT }\end{array}$ \\
\hline rs3135506 & S19W & $\begin{array}{l}\text { 1st-P } \\
\text { 2nd-P } \\
\text { UEP_SEQ }\end{array}$ & $\begin{array}{l}\text { ACGTTGGATGTGGTCTGGCTGAAGTAGTCC } \\
\text { ACGTTGGATGTGATTACCTAGTCCCTCTCC } \\
\text { TAGGCCCTCTCCACAGCGTTTT }\end{array}$ \\
\hline rs2075291 & $553 \mathrm{G}>\mathrm{T}$ & $\begin{array}{l}\text { 1st-P } \\
\text { 2nd-P } \\
\text { UEP_SEQ }\end{array}$ & $\begin{array}{l}\text { ACGTTGGATGTTGGGCTTTGCTGCAGGGAC } \\
\text { ACGTTGGATGATGGGTGGAAGAGCTCTTTG } \\
\text { GCTCTTTGAAGCGGC }\end{array}$ \\
\hline
\end{tabular}

SNP, single nucleotide polymorphism.

Table II. Frequencies of the genotype and allele for SNPs.

\section{A, $553 \mathrm{G}>\mathrm{T}$}

\begin{tabular}{|c|c|c|c|c|c|c|c|c|c|c|c|}
\hline \multirow[b]{2}{*}{ Total } & \multicolumn{3}{|c|}{ Genotype (n) } & \multirow[b]{2}{*}{$\chi^{2}$} & \multirow{2}{*}{$\begin{array}{c}\text { P-value, } \\
\mathrm{df}=2\end{array}$} & \multirow[b]{2}{*}{ HWE } & \multicolumn{2}{|c|}{ Allele (n) } & \multirow[b]{2}{*}{$\chi^{2}$} & \multirow{2}{*}{$\begin{array}{l}\text { P-value, } \\
\quad \mathrm{df}=1\end{array}$} & \multirow[b]{2}{*}{ OR $(95 \% \mathrm{CI})$} \\
\hline & GG & GT & $\mathrm{TT}$ & & & & G & $\mathrm{T}$ & & & \\
\hline $\begin{array}{l}\text { CHD cases, } \\
n=290\end{array}$ & 258 & 31 & 1 & & & 1.000 & 547 & 33 & & & \\
\hline $\begin{array}{l}\text { Non-CHD controls, } \\
n=198\end{array}$ & 169 & 29 & 0 & 2.357 & 0.261 & 0.605 & 367 & 29 & 1.056 & 0.352 & $0.764(0.456-1.279)$ \\
\hline $\begin{array}{l}\text { Healthy controls, } \\
n=331\end{array}$ & 299 & 31 & 1 & 0.312 & 0.799 & 0.567 & 629 & 33 & 0.305 & 0.614 & $1.150(0.700-1.888)$ \\
\hline
\end{tabular}

$\mathrm{B},-1131 \mathrm{~T}>\mathrm{C}$

\begin{tabular}{|c|c|c|c|c|c|c|c|c|c|c|c|}
\hline \multirow[b]{2}{*}{ Total } & \multicolumn{3}{|c|}{ Genotype (n) } & \multirow[b]{2}{*}{$\chi^{2}$} & \multirow{2}{*}{$\begin{array}{l}\text { P-value, } \\
\mathrm{df}=2\end{array}$} & \multirow[b]{2}{*}{ HWE } & \multicolumn{2}{|c|}{ Allele (n) } & \multirow[b]{2}{*}{$\chi^{2}$} & \multirow{2}{*}{$\begin{array}{l}\text { P-value, } \\
\quad \mathrm{df}=1\end{array}$} & \multirow[b]{2}{*}{ OR $(95 \% \mathrm{CI})$} \\
\hline & AA & $\mathrm{AG}$ & GG & & & & A & $\mathrm{G}$ & & & \\
\hline $\begin{array}{l}\text { CHD cases, } \\
n=290\end{array}$ & 134 & 124 & 32 & & & 0.685 & 392 & 188 & & & \\
\hline $\begin{array}{l}\text { Non-CHD controls, } \\
n=198\end{array}$ & 106 & 75 & 17 & 2.675 & 0.257 & 0.476 & 287 & 109 & 2.656 & 0.107 & $1.263(0.954-1.672)$ \\
\hline $\begin{array}{l}\text { Healthy controls, } \\
n=331\end{array}$ & 182 & 117 & 32 & 4.808 & 0.090 & 0.051 & 481 & 181 & 3.809 & 0.054 & $1.275(0.999-1.626)$ \\
\hline
\end{tabular}

SNP, single nucleotide polymorphism; HWE, Hardy-Weinberg equilibrium; OR, odds ratio; CI, confidence interval; CHD, coronary heart disease.

analysis by gender did not produce significant results between the 2 variants and the risk of CHD (data not shown).

Correlation between the 2 variants and the severity of CHD. The severity of CHD was defined by the number of coronary arteries with $>50 \%$ coronary artery occlusion. A logistic regression test was performed between the 2 variants and the severity of CHD in all cases and in a gender-stratified manner. The results indicated that $553 \mathrm{G}>\mathrm{T}$ correlated with $\mathrm{CHD}$ severity in males (Table IV; $\mathrm{P}=0.032$ ); however, following Bonferroni's correction, this result was not statistically significant.

Inclusion of case-control studies for meta-analysis. A total of 23 association studies between APOA5 gene variants and the risk of CHD were retrieved from the online databases. Among them, 9 studies were excluded from the current meta-analysis 
Table III. Significant differences in genotype distributions under the dominant model.

\begin{tabular}{|c|c|c|c|c|}
\hline \multirow[b]{2}{*}{ Dominant model } & \multicolumn{2}{|c|}{ CHD cases vs. non-CHD controls } & \multicolumn{2}{|c|}{ CHD cases vs. healthy controls } \\
\hline & OR $(95 \% \mathrm{CI})$ & P-value, $\mathrm{df}=1$ & OR $(95 \% \mathrm{CI})$ & P-value, $\mathrm{df}=1$ \\
\hline \multicolumn{5}{|l|}{ Total } \\
\hline rs2075291 (GT + TT vs. GG) & $0.723(0.422-1.239)$ & 0.266 & $1.159(0.691-1.945)$ & 0.599 \\
\hline rs662799 (AG + GG vs. AA) & $1.341(0.934-1.927)$ & 0.118 & $1.422(1.036-1.952)$ & 0.030 \\
\hline \multicolumn{5}{|l|}{ Male } \\
\hline rs2075291 (GT + TT vs. GG) & $0.638(0.325-1.249)$ & 0.211 & $1.720(0.677-4.370)$ & 0.295 \\
\hline rs662799 (AG + GG vs. AA) & $1.343(0.834-2.163)$ & 0.229 & $1.499(0.903-2.488)$ & 0.126 \\
\hline \multicolumn{5}{|l|}{ Female } \\
\hline rs2075291 (GT + TT vs. GG) & $0.787(0.305-2.031)$ & 0.643 & $0.936(0.406-2.159)$ & 1.000 \\
\hline rs662799 (AG + GG vs. AA) & $1.515(0.834-2.753)$ & 0.178 & $1.664(0.998-2.774)$ & 0.054 \\
\hline
\end{tabular}

CHD, coronary heart disease; OR, odds ratio; CI, confidence interval.

Table IV. Logistic regression analysis of association of SNPs and the serious extent of CHD disease.

\begin{tabular}{lcccccc}
\hline Parameters & Non-CHD controls & One artery & Two arteries & 2Three arteries & rs2075291 & rs662799 \\
\hline Total & $\mathbf{1 9 8}$ & $\mathbf{1 0 6}$ & $\mathbf{6 5}$ & $\mathbf{1 1 9}$ & 0.091 & 0.283 \\
Male & $\mathbf{1 0 1}$ & $\mathbf{7 7}$ & $\mathbf{4 9}$ & $\mathbf{8 4}$ & 0.032 & 0.568 \\
Female & $\mathbf{9 7}$ & $\mathbf{2 9}$ & $\mathbf{1 6}$ & $\mathbf{3 5}$ & 0.898 & 0.219 \\
\hline
\end{tabular}

Numbers in bold represent cases of patients under the corresponding conditions, numbers in italic represent P-values which indicate the association of the SNPs with the serious extent of disease. SNP, single nucleotide polymorphism; CHD, coronary heart disease.

as they focused on other APOA5 variants (24-27) or did not present sufficient information on genotype or allele frequencies or OR values $(9,28-31)$. A total of 14 studies were included in the meta-analysis: $-1131 \mathrm{~T}>\mathrm{C}, 6,848$ cases and 5,452 controls; S19W, 7,644 cases and 10,610 controls; and $553 \mathrm{G}>\mathrm{T}, 4,450$ cases and 5,068 controls.

Meta-analysis of the association studies between -1131T>C and the risk of $C H D$. As shown in Fig. 1, the case-control study (CHD cases vs. non-CHD controls) and 8 other studies $(6-8,10,32-35)$ were included in the meta-analysis. Significant heterogeneity was observed among the 9 studies $\left(\mathrm{I}^{2}, 52 \% ; \chi^{2}, 16.83 ; \mathrm{df}, 8 ; \mathrm{P}=0.03\right)$. Due to the high heterogeneity of these studies, the groups were divided into 2 ethnic subgroups, European and Asian. A significant heterogeneity was observed among Europeans $(6,7,33,34)\left(\mathrm{I}^{2}, 70 \%\right.$; $\left.\chi^{2}, 10.00 ; \mathrm{df}, 3 ; \mathrm{P}=0.02\right)$ in contrast to minimal heterogeneity among Asians $(8,10,32,35)\left(\mathrm{I}^{2}, 0 \% ; \chi^{2}, 3.11 ; \mathrm{df}, 4 ; \mathrm{P}=0.54\right)$. A significant association between $-1131 \mathrm{~T}>\mathrm{C}$ and $\mathrm{CHD}$ risk was observed in European individuals (OR, 1.77; 95\% CI, 1.42-2.20; $\mathrm{P}<0.0001)$ and Asian subgroups (OR, 1.38; 95\% CI, $1.25-1.52 ; \mathrm{P}<0.0001)$. A significant difference was observed between the 2 subgroups $\left(\mathrm{I}^{2}, 75.8 \% ; \chi^{2}, 4.14 ; \mathrm{df}, 1 ; \mathrm{P}=0.04\right)$. Funnel plot analysis did not reveal publication bias (Fig. 2A).

Meta-analysis of association studies between $553 G>T$ and the risk of $C H D$. Using the fixed effect analysis model, the meta-analysis of $553 \mathrm{G}>\mathrm{T}$ showed a moderate heterogeneity among the 2 case-control studies $(14,36)$ and the current study $\left(\mathrm{I}^{2}, 64 \% ; \chi^{2}, 5.48 ; \mathrm{df}, 2 ; \mathrm{P}=0.06\right)$. Due to the moderate heterogeneity, the random effects analysis model was selected for meta-analysis (Fig. 3). The results showed that $553 \mathrm{G}>\mathrm{T}$ had no significant association with $\mathrm{CHD}(\mathrm{P}=0.40$; OR, 1.22; 95\% CI, 0.77-1.91). Funnel plot analysis did not reveal publication bias (Fig. 2B).

Meta-analysis of the association studies between S19W and the risk of $C H D$. Fig. 4 shows the results of meta-analysis of the associations between S19W and CHD. Since S19W was monomorphic in the samples, only 7 studies were included in the meta-analysis $(6,8,15,16,36-38)$. Under the random effects model, a significantly higher heterogeneity was observed $\left(\mathrm{I}^{2}, 70 \% ; \chi^{2}, 19.98 ; \mathrm{df}, 6, \mathrm{P}=0.003\right)$. An outlier OR-value was observed in 1 study (8) (OR, 99.20; 95\% CI, 6.10-1612.48). Following exclusion of the outlier, another meta-analysis was performed and a lower heterogeneity was observed with fixed effect analysis model (Fig. 4; $\mathrm{I}^{2}, 40 \% ; \chi^{2}, 8.35$; df, 5; P=0.14). The results showed that $\mathrm{S} 19 \mathrm{~W}$ had no significant association with CHD (OR, 1.11; 95\% CI, 0.97-1.27; P=0.13). Funnel plot analysis did not reveal publication bias (Fig. 2C).

\section{Discussion}

The APOA5 gene codes for a 366-amino acid protein, apoA-V, which enhances lipoprotein lipase (LPL) activity (24). Loss of LPL activity interferes with the ability of apoA-V to interact 


\begin{tabular}{|c|c|c|c|c|c|c|c|c|c|c|}
\hline \multirow{2}{*}{$\begin{array}{l}\text { Studv or Subgroup } \\
\text { 1.1.1 European }\end{array}$} & $\begin{array}{l}\text { Case } \\
\text { Events }\end{array}$ & Total & $\begin{array}{l}\text { Control } \\
\text { Events T }\end{array}$ & Iotal & Weight & $\begin{array}{c}\text { Odds Ratio } \\
\text { M-H.Fixed, } 95 \% \mathrm{Cl}\end{array}$ & \multicolumn{4}{|c|}{$\begin{array}{l}\text { Odds Ratio } \\
\text { M-H, Fixed. } 95 \% \mathrm{Cl}\end{array}$} \\
\hline & & & & & & & & & & \\
\hline 2004 Csaba Szalai & 67 & 616 & 35 & 620 & $4.0 \%$ & $2.04[1.33,3.12]$ & & & & \\
\hline 2006 Havasi V & 70 & 604 & 28 & 578 & $3.2 \%$ & $2.57[1.64,4.06]$ & & & & \\
\hline 2007 Martinelli N & 130 & 1338 & 43 & 488 & $7.3 \%$ & $1.11[0.78,1.60]$ & & & & \\
\hline 2008 Maasz A & 80 & 756 & 13 & 262 & $2.2 \%$ & $2.27[1.24,4.15]$ & & & & \\
\hline Subtotal $(95 \% \mathrm{Cl})$ & & 3314 & & 1948 & $16.8 \%$ & $1.77[1.42,2.20]$ & & & & \\
\hline Total events & 347 & & 119 & & & & & & & \\
\hline \multicolumn{11}{|c|}{ Heterogeneity: $\mathrm{Chi}^{2}=10.00, \mathrm{df}=3(\mathrm{P}=0.02) ; \mathrm{I}^{2}=70 \%$} \\
\hline \multicolumn{11}{|c|}{ Test for overall effect: $Z=5.10(P<0.00001)$} \\
\hline \multicolumn{11}{|l|}{ 1.1.2 Asian } \\
\hline 2005 Yan, S. & 84 & 226 & 86 & 310 & $5.9 \%$ & $1.54[1.07,2.22]$ & & & $\longrightarrow$ & \\
\hline 2005 Liu, H. & 378 & 966 & 300 & 1004 & $23.0 \%$ & $1.51[1.25,1.82]$ & & & $\rightarrow$ & \\
\hline 2007 Yu, Y. & 121 & 280 & 103 & 312 & $7.1 \%$ & $1.54[1.11,2.16]$ & & & $\longrightarrow$ & \\
\hline 2009 Jang $Y$ & 499 & 1482 & 423 & 1482 & $36.0 \%$ & $1.27[1.09,1.49]$ & & & $\Rightarrow$ & \\
\hline 2012 our study & 188 & 580 & 109 & 396 & $11.2 \%$ & $1.26[0.95,1.67]$ & & & - & \\
\hline Subtotal $(95 \% \mathrm{Cl})$ & & 3534 & & 3504 & $83.2 \%$ & $1.38[1.25,1.52]$ & & & $\checkmark$ & \\
\hline Total events & 1270 & & 1021 & & & & & & & \\
\hline \multirow{2}{*}{\multicolumn{11}{|c|}{$\begin{array}{l}\text { Heterogeneity: } \mathrm{Chi}^{2}=3.11, \mathrm{df}=4(P=0.54) ; I^{2}=0 \% \\
\text { Test for overall effect: } Z=6.24(P<0.00001)\end{array}$}} \\
\hline & & & & & & & & & & \\
\hline Total $(95 \% \mathrm{Cl})$ & & 6848 & & 5452 & $100.0 \%$ & $1.44[1.32,1.58]$ & & & 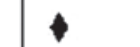 & \\
\hline Total events & 1617 & & 1140 & & & & & & & \\
\hline \multicolumn{7}{|c|}{ Heterogeneity: $\mathrm{Chi}^{2}=16.83, \mathrm{df}=8(\mathrm{P}=0.03) ; \mathrm{I}^{2}=52 \%$} & 0.2 & 0.5 & 1 & 5 \\
\hline \multicolumn{7}{|c|}{ Test for overall effect: $Z=7.89(P<0.00001)$} & 0.2 & & Increas & \\
\hline
\end{tabular}

Figure 1. Correlation between rs662799 (-1131T>C) and CHD in the meta-analysis. Events, the number of G alleles; total, total number of A and G alleles; our study, the CHD cases vs. non-CHD controls in our study; $\mathrm{CHD}$, coronary heart disease.

with lipids and lipoproteins, including TGs, very low density lipoproteins and high density lipoproteins $(39,40)$. Elevated plasma TGs are a known risk factor for CHD $(41,42)$ and apoA-V is a major risk factor of CHD as it activates TG hydrolysis in the blood (43). APOA5 gene variants have been identified as the genetic determinants of TG concentration (9). Since discrepancies exist in previous epidemiological studies on the association of APOA5 gene variants with $\mathrm{CHD}$, the current study investigated a case-control study in specific populations and meta-analysis of the available case-control data was performed to clarify the role of APOA5 gene variants in CHD.

SNP -1131T $>C$ is located in the proximal promoter of the APOA5 gene and is associated with elevated TG levels and hyperinsulinemia (2). A number of studies have found that the $-1131 \mathrm{~T}>\mathrm{C}$ gene is significantly associated with CHD in Chinese populations $(8,10,32)$. However, the association between $-1131 \mathrm{~T}>\mathrm{C}$ and CHD in the European population remains controversial $(6,7,33,34)$. Three independent studies $(7,33,34)$ observed that patients carrying the $-1131 \mathrm{CT}>\mathrm{C}$ gene had higher TG levels and a significantly increased risk of coronary events. However, Martinelli et al demonstrated that 2 APOA5 variants, including $-1131 \mathrm{~T}>\mathrm{C}$, which are independent predictors of TGs (6), were not associated with CHD (6). The current meta-analysis of 9 studies among 12,300 individuals indicates that $-1131 \mathrm{CT}>\mathrm{C}$ is a risk factor for CHD (pooled OR, 1.44; 95\% CI, 1.32-1.58; $\mathrm{P}<0.00001)$. An ethnic difference in the prevalence of $-1131 \mathrm{~T}>\mathrm{C}$ was observed between the Asian and the European studies $\left(\mathrm{I}^{2}, 5.8 \% ; \mathrm{P}=0.04\right)$. The frequency of $-1131 \mathrm{CT}>\mathrm{C}$ in non-CHD controls and healthy controls was 0.380 and 0.376 , respectively, which is close to 0.267 in HapMap-HCB and 0.291 in HapMap-JPT (http://www.ncbi.nlm.nih.gov/projects/SNP/snp_ ref.cgi?rs=662799). A lower frequency of $-1131 \mathrm{C}$ was observed
$\mathbf{A}$

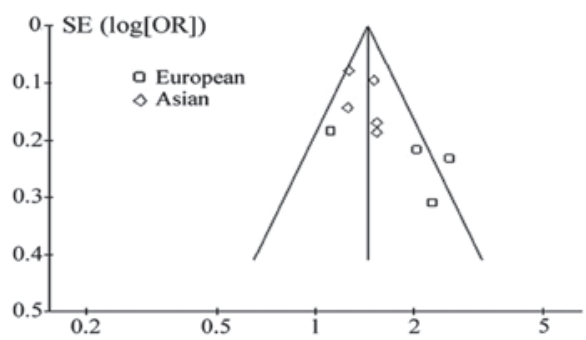

B

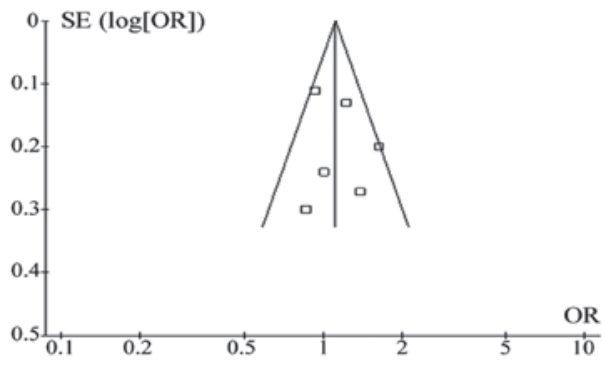

$\mathbf{C}$

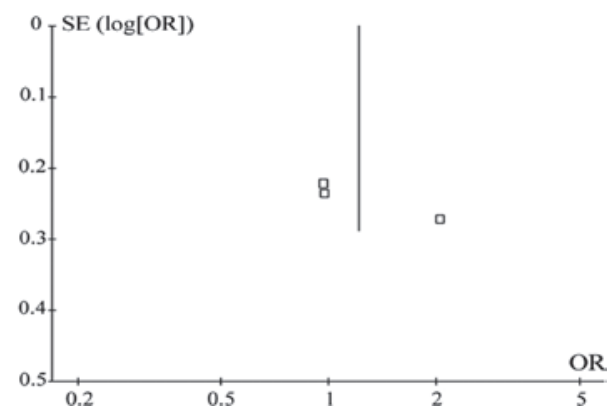

Figure 2. Funnel plot of the 3 SNPs in the APOA5 gene in the meta-analysis, (A) rs662799 $(-1131 \mathrm{~T}>\mathrm{C}),(\mathrm{B}) \mathrm{rs} 2075291(553 \mathrm{G}>\mathrm{T})$ and $(\mathrm{C}) \mathrm{rs} 3135506$ (S19W). APOA5, apolipoprotein A5; SNP, single nucleotide polymorphisms. 


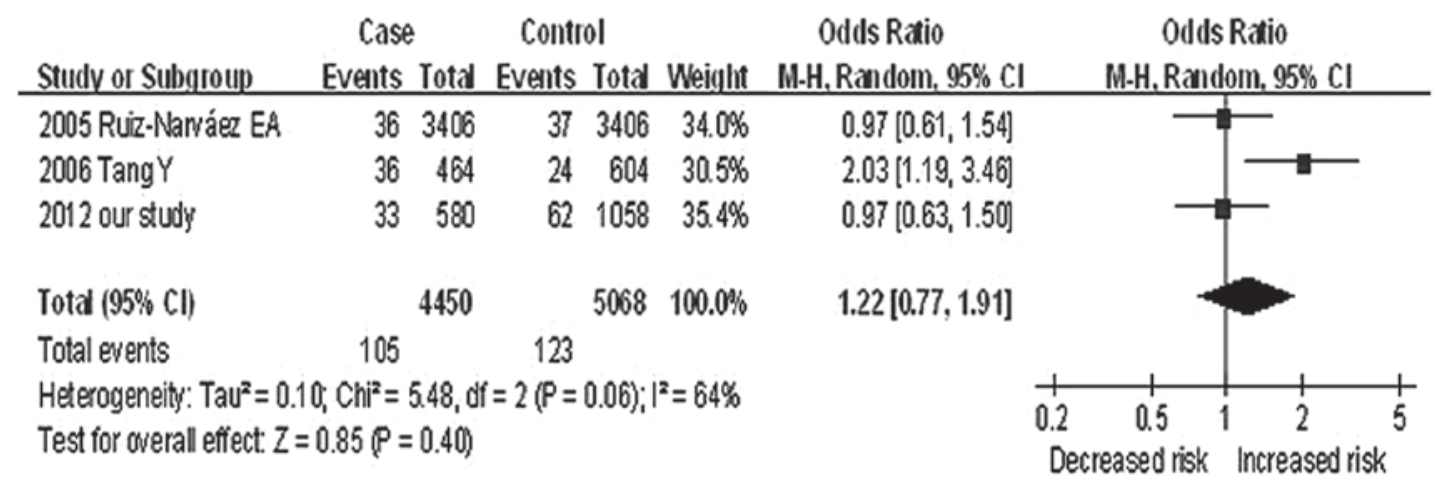

Figure 3. Correlation between rs2075291 (553G $>\mathrm{T}$ ) and CHD in the meta-analysis. Events, the number of $\mathrm{T}$ alleles; total, total number of $\mathrm{G}$ and $\mathrm{T}$ alleles; our study, the CHD cases vs. diagnosed controls and healthy controls in our study; CHD, coronary heart disease.

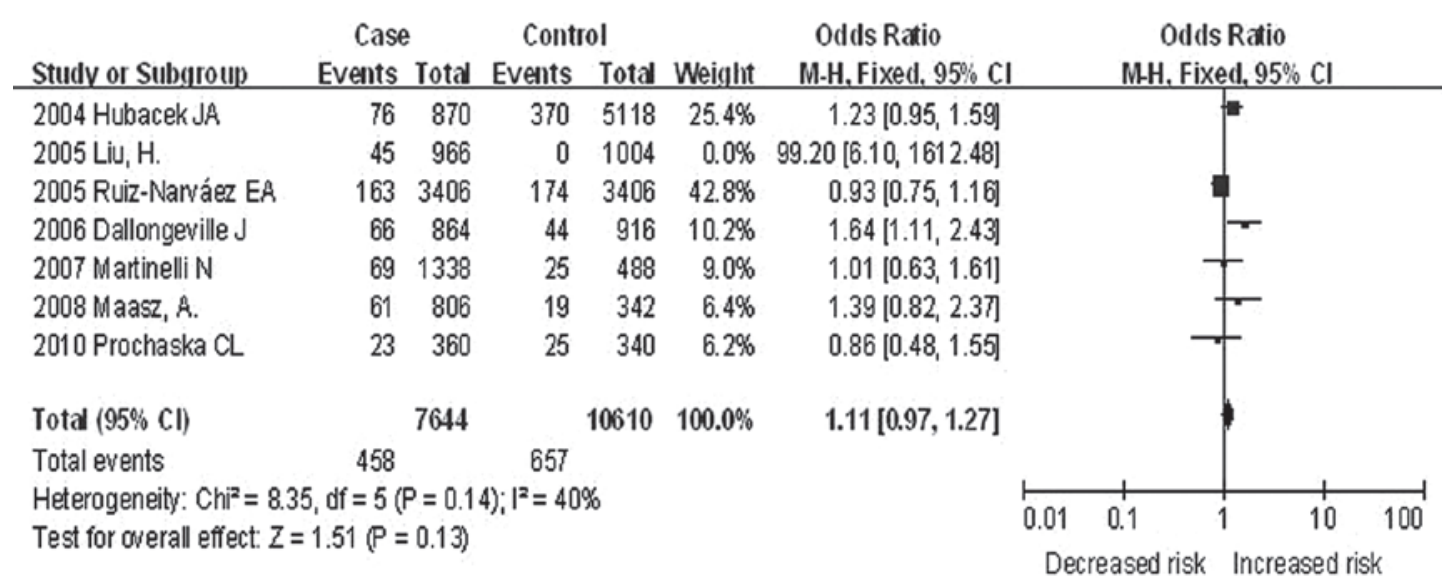

Figure 4. Correlation between rs3135506 (S19W) and CHD in the meta-analysis. Events, the number of C alleles; Total, total number of C and G alleles; CHD, coronary heart disease.

in Europeans (0.017 in HapMap-CEU). This is in agreement with the current heterogeneity test results in the meta-analysis.

SNP 553G $>$ T is a rare APOA5 gene variant that has been studied in Han Chinese populations (13,14,29,36). SNP 553G $>$ T has been found to correlate with serum levels of TG and total cholesterol in Han Chinese individuals in Xinjiang, China (29). A significant association between 553G $>$ T and CHD in Han Chinese populations, by 2 separate groups, has been found in Taiwan $(\mathrm{P}<0.001)$ and Nanjing $(\mathrm{P}=0.017)(13,14)$. In the present study, the previous positive association between $553 \mathrm{G}>\mathrm{T}$ and CHD was not observed. A meta-analysis of 3 studies among 9,518 individuals indicates that the $553 \mathrm{G}>\mathrm{T}$ gene is not associated with $\mathrm{CHD}$ risk ( $\mathrm{P}=0.40$; OR, 1.22; 95\% CI, 0.77-1.91). However, a correlation between $553 \mathrm{G}>\mathrm{T}$ and the severity of $\mathrm{CHD}$ was observed in males by a logistic regression analysis $(\mathrm{P}=0.032)$. Further investigation of the contribution of $553 \mathrm{G}>\mathrm{T}$ to the progression of CHD is required.

The minor allele frequency of S19W in Chinese populations was significantly different from that in Caucasians. The 19W allele is rare in HapMap-CHB (0\%), thus providing an explanation as to why $\mathrm{S} 19 \mathrm{~W}$ was monomorphic in the samples, including 290 CHD cases, 198 non-CHD controls and 331 healthy controls. Liu et al observed a $4.7 \%$ prevalence of $19 \mathrm{~W}$ in the CHD cases, while in Chinese populations, 19W was not observed $(0 \%)$ (8). However, another case-control study in Chinese populations did not observe $19 \mathrm{~W}$ in cases and controls and thus, hypothesized a negative association between SNP 19W and CHD $(11,44)$. The allele frequency of $19 \mathrm{~W}$ was $0.1 \%$ in Chinese Singaporean populations (12). However, $19 \mathrm{~W}$ was more common in Europeans (HapMap-CEU: 5.8\%). The allele frequencies of $19 \mathrm{~W}$ in Malay and the Asian-Indian populations were 1.7 and $3.1 \%$, respectively, while in Latin-American populations, allele frequency was $15 \%$ (12). The current meta-analysis of 6 studies $(6,15,16,36-38)$ among 18,254 individuals found no significant association between CHD and S19W ( $\mathrm{P}=0.13$; OR, 1.11; 95\% CI, 0.97-1.27).

In summary, the current case-control study shows that the $-1131 \mathrm{CT}>\mathrm{C}$ gene is a CHD risk factor in the populations studied and this association was further supported by meta-analysis. The case-control study has $<80 \%$ statistical power (the strongest power observed for $-1131 \mathrm{~T}>\mathrm{C}$ was $58.8 \%$ ). An improved case-control investigation with larger sample sizes and a balanced gender structure is required in the future.

\section{Acknowledgements}

The research was supported by the grants from the National Natural Science Foundation of China (31100919), Natural Science Foundation of Zhejiang Province (LR13H020003), K.C. Wong Magna Fund in Ningbo University, Ningbo Social 
Development Research Projects (2012C50032), Advanced Key Scientific and Technological Programs of NingBo (2011C51001), Fund of NingBo Science and Technology Innovation Team (2011B82015), Natural Science Foundation of the Zhejiang Province (LY13H020008), Ningbo Personnel Training Project (first level), and the Project of Ningbo Medicine and Science (2009A02).

\section{References}

1. Carey VJ, Bishop L, Laranjo N, Harshfield BJ, Kwiat C and Sacks FM: Contribution of high plasma triglycerides and low high-density lipoprotein cholesterol to residual risk of coronary heart disease after establishment of low-density lipoprotein cholesterol control. Am J Cardiol 106: 757-763, 2010.

2. Maász A, Kisfali P, Horvatovich K, et al: Apolipoprotein A5 T-1131C variant confers risk for metabolic syndrome. Pathol Oncol Res 13: 243-247, 2007.

3. Evans D, Aberle J and Beil FU: Resequencing the apolipoprotein A5 (APOA5) gene in patients with various forms of hypertriglyceridemia. Atherosclerosis 219: 715-720, 2011.

4. Peden JF and Farrall M: Thirty-five common variants for coronary artery disease: the fruits of much collaborative labour. Hum Mol Genet 20: R198-R205, 2011.

5. Pennacchio LA, Olivier M, Hubacek JA, Cohen JC, Cox DR, Fruchart JC, Krauss RM and Rubin EM: An apolipoprotein influencing triglycerides in humans and mice revealed by comparative sequencing. Science 294: 169-173, 2001.

6. Martinelli N, Trabetti E, Bassi A, Girelli D, Friso S, Pizzolo F, Sandri M, Malerba G, Pignatti PF, Corrocher R and Olivieri O: The -1131 T $>$ C and S19W APOA5 gene polymorphisms are associated with high levels of triglycerides and apolipoprotein C-III, but not with coronary artery disease: an angiographic study. Atherosclerosis 191: 409-417, 2007.

7. Szalai C, Keszei M, Duba J, Prohászka Z, Kozma GT, Császár A Balogh S, Almássy Z, Fust G and Czinner A: Polymorphism in the promoter region of the apolipoprotein A5 gene is associated with an increased susceptibility for coronary artery disease. Atherosclerosis 173: 109-114, 2004.

8. Liu H, Zhang S, Lin J, et al: Association between DNA variant sites in the apolipoprotein A5 gene and coronary heart disease in Chinese. Metabolism 54: 568-572, 2005.

9. Triglyceride Coronary Disease Genetics Consortium and Emerging Risk Factors Collaboration; Sarwar N, Sandhu MS Ricketts SL, et al: Triglyceride-mediated pathways and coronary disease: collaborative analysis of 101 studies. Lancet 375: $1634-1639,2010$.

10. Yu Y, Xue L and Zhao CY: Study on polymorphism in the apolipoprotein A5 gene in patients with premature coronary heart disease. Beijing Da Xue Xue Bao 39: 576-580, 2007 (In Chinese).

11. Li X, Yao C, Song M, Ma J, Ning H and Hu B: The relationship between the polymorphism of apolipoprotein A5 gene 56C $>\mathrm{G}$ and the level of serum triglyceride. Ningxia Yi Xue Za Zhi 9: 643-645, 2006 (In Chinese).

12. Lai CQ, Tai ES, Tan CE, Cutter J, Chew SK, Zhu YP, Adiconis X and Ordovas JM: The APOA5 locus is a strong determinant of plasma triglyceride concentrations across ethnic groups in Singapore. J Lipid Res 44: 2365-2373, 2003.

13. Kao JT, Wen HC, Chien KL, Hsu HC and Lin SW: A novel genetic variant in the apolipoprotein A5 gene is associated with hypertriglyceridemia. Hum Mol Genet 12: 2533-2539, 2003.

14. Tang Y, Sun P, Guo D, Ferro A, Ji Y, Chen Q and Fan L: A genetic variant c. $553 \mathrm{G}>\mathrm{T}$ in the apolipoprotein $\mathrm{A} 5$ gene is associated with an increased risk of coronary artery disease and altered triglyceride levels in a Chinese population. Atherosclerosis 185: 433-437, 2006

15. Prochaska CL, Picheth G, Anghebem-Oliveira MI, Costantini CO, de Souza EM, Pedrosa FO and Scartezini M: The polymorphisms $-1131 \mathrm{~T}>\mathrm{C}$ and the $\mathrm{S} 19 \mathrm{~W}$ of the APOA5 gene are not associated with coronary artery disease in a Brazilian population. Clin Chem Lab Med 48: 419-422, 2010.

16. Maász A, Kisfali P, Szolnoki Z, Hadarits F and Melegh B: Apolipoprotein A5 gene C56G variant confers risk for the development of large-vessel associated ischemic stroke. J Neurol 255: 649-654, 2008
17. No authors listed: Nomenclature and criteria for diagnosis of ischemic heart disease. Report of the Joint International Society and Federation of Cardiology/World Health Organization task force on standardization of clinical nomenclature. Circulation 59: 607-609, 1979.

18. Nikus KC: Chapter 4: Coranory angiography. In: Multimodal Imaging: Principles and Clinical Applications: Section I: Current methods and their applications for cardiovascular multimodal imaging. Pahlm $\mathrm{O}$ and Wagner GS (eds). McGraw-Hill Medical, New York, NY, p75, 2011.

19. Higgs ZC, Macafee DA, Braithwaite BD and Maxwell-Armstrong CA: The Seldinger technique: 50 years on. Lancet 366: 1407-1409, 2005.

20. Gabriel S, Ziaugra L and Tabbaa D: SNP genotyping using the Sequenom MassARRAY iPLEX platform. Curr Protoc Hum Genet (Suppl 60): 2.12.1-2.12.18, 2009.

21. Excoffier L and Lischer HE: Arlequin suite ver 3.5: a new series of programs to perform population genetics analyses under Linux and Windows. Mol Ecol Resour 10: 564-567, 2010.

22. Sham PC and Curtis D: Monte Carlo tests for associations between disease and alleles at highly polymorphic loci. Ann Hum Genet 59 (Pt 1): 97-105, 1995.

23. Dupont WD and Plummer WD Jr: Power and sample size calculations. A review and computer program. Control Clin Trials 11: $116-128,1990$

24. Aberle J, Evans D, Beil FU and Seedorf U: A polymorphism in the apolipoprotein A5 gene is associated with weight loss after short-term diet. Clin Genet 68: 152-154, 2005.

25. Liu HK, Wang CT, Zhang SZ, et al: Association of APOA5 gene single nucleotide polymorphism with levels of lipids and coronary heart disease in Chinese. Zhonghua Yi Xue Yi Chuan Xue Za Zhi 21: 335-338, 2004 (In Chinese).

26. Yuan S, Ma YT, Xie X, Yang YN, Fu ZY, Ma X, Li XM, Xiang Y, Liu F and Chen BD: Association of apolipoprotein A5 gene polymorphism with coronary heart disease in Uygur population of Xinjiang. Zhonghua Yi Xue Yi Chuan Xue Za Zhi 28: 73-77, 2011 (In Chinese).

27. Hubacek JA, Wang WW, Skodová Z, Adámková V, Vráblík M, Horínek A, Stulc T, Ceska R and Talmud PJ: APOA5 Ala315>Val, identified in patients with severe hypertriglyceridemia, is a common mutation with no major effects on plasma lipid levels. Clin Chem Lab Med 46: 773-777, 2008.

28. Eichenbaum-Voline S, Olivier M, Jones EL, et al: Linkage and association between distinct variants of the APOA1/C3/A4/A5 gene cluster and familial combined hyperlipidemia. Arterioscler Thromb Vasc Biol 24: 167-174, 2004.

29. Yuan S, Ma YT, Xie X, Yang YN, Fu ZY, Ma X, Li XM, Liu F and Chen BD: Association between apolipoprotein A5 gene polymorphism and coronary heart disease in the Han population from Xinjiang. Zhonghua Liu Xing Bing Xue Za Zhi 32: 51-54, 2011 (In Chinese)

30. Song KH, Yu SG, Cha S and Kim JY: Association of the Apolipoprotein A5 gene $-1131 \mathrm{~T}>\mathrm{C}$ polymorphism with serum lipids in Korean subjects: impact of Sasang constitution. Evid Based Complement Alternat Med 2012: 598394, 2012.

31. Ramakrishnan L, Sachdev HS, Sharma M, et al: Relationship of APOA5, PPAR $\gamma$ and HL gene variants with serial changes in childhood body mass index and coronary artery disease risk factors in young adulthood. Lipids Health Dis 10: 68, 2011.

32. Yan SK, Cheng XQ, Song YH, Xiao XH, Bi N and Chen BS Apolipoprotein A5 gene polymorphism $-1131 \mathrm{~T} \rightarrow \mathrm{C}$ : association with plasma lipids and type 2 diabetes mellitus with coronary heart disease in Chinese. Clin Chem Lab Med 43: 607-612, 2005.

33. Havasi V, Szolnoki Z, Talián G, et al: Apolipoprotein A5 gene promoter region T-1131C polymorphism associates with elevated circulating triglyceride levels and confers susceptibility for development of ischemic stroke. J Mol Neurosci 29: 177-183, 2006.

34. Maasz A, Kisfali P, Jaromi L, Horvatovich K, Szolnoki Z, Csongei V, Safrany E, Sipeky C, Hadarits F and Melegh B: Apolipoprotein A5 gene IVS3+G476A allelic variant confers susceptibility for development of ischemic stroke. Circ J 72: 1065-1070, 2008

35. Jang Y, Paik JK, Hyun YJ, Chae JS, Kim JY, Choi JR, Lee SH, Shin DJ, Ordovas JM and Lee JH: The apolipoprotein A5 $-1131 \mathrm{~T}>\mathrm{C}$ promoter polymorphism in Koreans: association with plasma APOA5 and serum triglyceride concentrations, LDL particle size and coronary artery disease. Clin Chim Acta 402: 83-87, 2009. 
36. Ruiz-Narváez EA, Yang Y, Nakanishi Y, Kirchdorfer J and Campos H: APOC3/A5 haplotypes, lipid levels, and risk of myocardial infarction in the Central Valley of Costa Rica. J Lipid Res 46: 2605-2613, 2005.

37. Hubacek JA, Skodová Z, Adámková V, Lánská V and Poledne R: The influence of APOAV polymorphisms (T-1131>C and S19>W) on plasma triglyceride levels and risk of myocardial infarction. Clin Genet 65: 126-130, 2004

38. Dallongeville J, Cottel D, Montaye M, Codron V, Amouyel P and Helbecque N: Impact of APOA5/A4/C3 genetic polymorphisms on lipid variables and cardiovascular disease risk in French men. Int J Cardiol 106: 152-156, 2006.

39. Dorfmeister B, Zeng WW, Dichlberger A, et al: Effects of six APOA5 variants, identified in patients with severe hypertriglyceridemia, on in vitro lipoprotein lipase activity and receptor binding. Arterioscler Thromb Vasc Biol 28: 1866-1871, 2008.
40. Johansen CT, Kathiresan S and Hegele RA: Genetic determinants of plasma triglycerides. J Lipid Res 52: 189-206, 2011.

41. Lim S, Park YM, Sakuma I and Koh KK: How to control residual cardiovascular risk despite statin treatment: Focusing on HDL-cholesterol. Int J Cardiol 166: 8-14, 2013.

42. Hokanson JE and Austin MA: Plasma triglyceride level is a risk factor for cardiovascular disease independent of high-density lipoprotein cholesterol level: a meta-analysis of population-based prospective studies. J Cardiovasc Risk 3: 213-219, 1996.

43. Merkel M and Heeren J: Give me A5 for lipoprotein hydrolysis! J Clin Invest 115: 2694-2696, 2005.

44. Li G, Wang JY, Yan S, Zhang LJ, Xue H, Zeng WW, Wu G and Chen BS: The relationship between the polymorphism of apolipoprotein $\mathrm{A} 5$ gene $56 \mathrm{C} \rightarrow \mathrm{G}$ and the levels of serum triglyceride. Zhonggua Dong Mai Ying Hua Za Zhi 5: 574-576, 2004 (In Chinese). 